\title{
In Vitro Evaluation of Microleakage of Different Materials Used as Pit-and-Fissure Sealants
}

\author{
Vanessa PARDI ${ }^{1}$ \\ Mário Alexandre Coelho SINHORETI \\ Antonio Carlos PEREIRA ${ }^{3}$ \\ Gláucia Maria Bovi AMBROSANO3 \\ Marcelo de Castro MENEGHIM ${ }^{3}$ \\ ${ }^{1}$ Graduate Program in Community Health, University of the Sacred Heart (USC), Bauru, SP, Brazil \\ ${ }^{2}$ Department of Restorative Dentistry and ${ }^{3}$ Department of Community Dentistry, Faculty of Dentistry of Piracicaba, State \\ University of Campinas (UNICAMP), Piracicaba, SP, Brazil
}

\begin{abstract}
The aim of this study was to evaluate in vitro the marginal microleakage of different materials used as pit-and-fissure sealants (Delton, Filtek Flow, Dyract Flow and Vitremer). Fifty-six extracted sound human third molars were randomly assigned to 4 groups (n=14). After sealant placement, the teeth were thermocycled $\left(500\right.$ cycles; $5^{\circ} \mathrm{C}, 37^{\circ} \mathrm{C}$ and $55^{\circ} \mathrm{C}$ ), isolated, immersed in $2 \%$ buffered methylene blue dye for $4 \mathrm{~h}$, included in acrylic resin and sectioned longitudinally in a buccolingual direction. The sections were analyzed for leakage using an stereomicroscope. A 4-criteria ranked scale was used to score dye penetration. All materials exhibited dye penetration to some extension and no statistically significant difference was observed among the groups ( $\mathrm{p}>0.05)$. In conclusion, the findings of this study showed that a flowable composite resin, a flowable compomer and resin-modified glass ionomer placed on occlusal pits and fissures had similar marginal sealing as the unfilled self-cured resin-based sealant.
\end{abstract}

Key Words: prevention, pit-and-fissure sealants, dental materials, microleakage.

\section{INTRODUCTION}

Caries prevalence decline over the last decades has been well documented and has led to changes in the pattern (proportionately fewer smooth surface lesions than pit-and-fissure lesions) and progression velocity (1). Nevertheless, occlusal caries account for $56 \%$ to $70 \%$ of the lesions in children aged 5 to 17 years $(2,3)$. Fissure sealing is an established and effective approach for caries management on occlusal surfaces (4).

Occlusal caries has become increasingly more difficult to be detected because the typical cavity design in enamel is not present in many cases (5). The so-called hidden caries is described as occlusal dentin caries that is missed on visual exam but detected radiographically or upon fissure biopsy (6). Caries diagnosis is an essential prerequisite when sealant placement is considered because hidden caries can be inadvertently sealed when bitewing radiographs are not taken.

The marginal sealing ability of sealing materials is extremely important for successful treatment. Lack of sealing allows the occurrence of marginal leakage, i.e., passage of bacteria, fluids, molecules and ions through the tooth-material interface (7), which can prompt caries lesion progression underneath the restoration. In vitro microleakage studies can predict the marginal sealing ability of restorative materials (8). Therefore, the purpose of this study was to evaluate in vitro the microleakage of different materials used as pit-andfissure sealants.

\section{MATERIAL AND METHODS}

Fifty-six extracted human third molars free of cracks, caries and restorations were selected, cleaned with periodontal curettes and pumice prophylaxis and

Correspondence: Dr. Mário Alexandre Coelho Sinhoreti, Faculdade de Odontologia de Piracicaba, UNICAMP, Área Materiais Dentários, Av. Limeira, 901, 13414-903 Piracicaba, SP, Brasil. Tel: +55-19-3412-5374. Fax: +55-19-3412-5218. e-mail: sinhoret@fop.unicamp.br 
stored in distilled water at $4^{\circ} \mathrm{C}$. The teeth were randomly assigned to 4 groups $(n=14)$, according to the material used as pit-and-fissure sealant: Delton self-cured unfilled resin-based sealant (Dentsply/Caulk, Milford, DE, USA); Filtek Flow flowable composite resin (3M/ESPE, St. Paul, MN, USA); Dyract Flow flowable compomer (Dentsply/Caulk) and Vitremer resin-modified glass ionomer (3M/ESPE).

No invasive technique (enameloplasty) was used prior to sealant placement. The occlusal surfaces were cleaned with pumice/water slurry in Robinson bristle brushes at slow speed, etched with a 37\% phosphoric acid gel (Dentsply/Caulk), rinsed with air/water spray for $5 \mathrm{~s}$ and dried with oil-free compressed air. The materials were placed according to the manufacturer's instructions, as follows. For Delton, the universal and catalyst liquids were mixed in a mixing dish, applied to the fissures with a disposable brush along the entire fissure extension and left self-curing. For Filtek Flow, Single Bond (3M/ESPE) adhesive system was applied, air-thinned and light-cured for $10 \mathrm{~s}$. The sealing material was applied to the pits and fissures along their entire extension with an explorer and light-cured for 20 s. For Dyract Flow, Prime-Bond NT (Dentsply/Caulk) adhesive system was applied, air-thinned and light-cured for 10 s. The sealing material was applied along their entire extension with an explorer and light-cured for 20 s. For Vitremer, Vitremer primer was applied, left act for $30 \mathrm{~s}$, air-thinned and light-cured for 20 s. Powder and liquid were mixed at a $1: 2$ ratio to obtain a low viscosity material that flowed easily into the fissures (9). The sealing material was applied to the pits and fissures with an explorer and light-cured for $40 \mathrm{~s}$. Vitremer Finishing Gloss was applied and light-cured for $20 \mathrm{~s}$.

The teeth were stored at $37^{\circ} \mathrm{C}$ and $100 \%$ relative humidity until thermocycling (500 cycles). In each cycle, the teeth were immersed in water baths at $5^{\circ} \mathrm{C}$ and $55^{\circ} \mathrm{C}$ ( $30 \mathrm{~s}$ in each), with an intermediary water bath at $37^{\circ} \mathrm{C}(10)$.

In preparation for dye penetration test, the root apexes were sealed with epoxy resin, and the teeth were coated with two layers of brown nail polish (CEIL, São Paulo, SP, Brazil) interposed by a layer of wax (Clássico, São Paulo, SP, Brazil), leaving exposed a 1.5-mm window around the sealant margins and immersed in $2 \%$ buffered methylene blue dye for $4 \mathrm{~h}$. Thereafter, the nail varnish and wax were removed with a sharp instrument and the teeth were rinsed, dried and embedded in chemically activated acrylic resin. After polymerization, the teeth/resin blocks were sectioned longitudinally in a buccolingual direction with a water-cooled diamond saw (Isomet, Buehler, Lake Bluff, IL, USA) thus providing 2 to 4 sections per tooth. The sections were examined in a X40/60 binocular microscope (Leitz, Carl Zeiss do Brasil, Manaus, AM, Brazil) and a ranked scale was used to score dye penetration (11): $0=$ no dye penetration; $1=$ dye penetration limited to the outer half of the sealant; 2 = dye penetration extending to the inner half of the sealant; $3=$ dye penetration extending to the underlying fissure.

Kruskal-Wallis non-parametric test was used to compare the groups for statistically significant differences at $5 \%$ significance level.

\section{RESULTS}

No sealant was lost. Microleakage scores are show in Table 1.

Most teeth sealed with Delton and Dyract Flow did not show dye penetration (score 0 ), but one tooth in each group was scored 3. Most teeth sealed with Vitremer and Filtek Flow had score 1, and none was scored 3. There were no statistically significant difference ( $>0.05$ ) among the groups regarding microleakage.

\section{DISCUSSION}

Pit-and-fissure sealants have been considered an outstanding adjunct to oral health care preventive strategies in the decrease of occlusal caries onset and/ or progression (4). The properties of an ideal sealing material include biocompatibility, retention and resistance to abrasion and wear (8). Sealant bonding to enamel is also important because microleakage at tooth-material interface can lead to treatment failure.

Table 1. Distribution of microleakage scores (0 to 3) $(n=14)$.

\begin{tabular}{lllll}
\hline \multirow{2}{*}{ Materials } & \multicolumn{4}{c}{ Scores } \\
\cline { 2 - 5 } & 0 & 1 & 2 & 3 \\
\hline Delton & 9 & 2 & 2 & 1 \\
Filtek Flow & 4 & 9 & 1 & 0 \\
Dyract Flow & 8 & 2 & 3 & 1 \\
Vitremer & 6 & 7 & 1 & 0 \\
\hline
\end{tabular}


In this study, the in vitro microleakage of four restorative materials used as pit-and-fissure sealants was evaluated. Dental materials specifically developed as fissure sealants have not changed greatly since the 1970's (4). Therefore, a resin-modified glass ionomer, a compomer and a flowable composite resin were evaluated as fissure sealants in addition to an unfilled resin-based sealant. All materials were applied without enameloplasty in order to observe the behavior of these materials without removal of tooth substance. The specimens were termocycled to reproduce the different temperatures to which the teeth are subjected during eating and drinking under clinical conditions.

The four materials hereby tested did not differ statistically in terms of marginal leakage. Rego and Araújo (12), investigating the microleakage of pit-andfissure sealants after surface preparation (invasive technique and laser irradiation) and use of different materials, found greater microleakage for the resin modified glass ionomer. The authors attributed this result to the fact that the enamel was not etched and this type of material has a resin component. In the present study, all teeth were acid-etched before sealant placement. Because it was an in vitro evaluation, moisture control was obtained. These facts might have contributed to explain the statistically similar behavior of the tested materials. In a previous study, Güngör et al. (13) also found that Dyract Flow and Delton-FS had comparable microleakage results.

According to the American Dental Association (14), fissure sealants can be placed in incipient caries on enamel. However, it is possible that teeth with dentin lesions under apparently sound enamel surfaces (hidden caries) are equivocally sealed (15). The marginal sealing is important for sealant success because penetration of bacteria beneath the sealant might allow caries onset and/or progression (16-17). It has also been advocated that, if complete caries removal is precluded or missed, the sealing ability of the filling material seems to be more important than its cariostatic properties (17).

Several studies (18-19) have investigated whether caries disease is arrested when dentin lesions are not completely removed. The findings of these works have shown a decrease in the number of cultivable microorganisms in infected dentin after sealant placement. Because of this beneficial effect of sealing dentin caries or incipient enamel caries, the sealing material should fill pits and fissures completely during sealant placement (17). Periodical clinical and radiographic (bitewing technique) controls is required for follow-up of this type of lesion (20).

The findings of this study showed that a flowable composite resin, a flowable compomer and a resinmodified glass ionomer placed on occlusal pits and fissures had similar marginal sealing as the unfilled selfcured resin-based sealant.

\section{RESUMO}

O objetivo desse estudo foi avaliar in vitro a microinfiltração marginal de diferentes materiais utilizados como selantes de fissuras (Delton, Filtek Flow, Dyract Flow and Vitremer). Cinqüenta e seis terceiros molares hígidos extraídos foram divididos aleatoriamente em 4 grupos $(n=14)$. Após a aplicação dos selantes, os dentes foram termociclados (500 ciclos com banhos entre $5^{\circ} \mathrm{C}, 37^{\circ} \mathrm{C}$ e $55^{\circ} \mathrm{C}$ ), isolados, imersos em azul de metileno tamponado a $2 \%$ por $4 \mathrm{~h}$, incluídos em resina acrílica e seccionados longitudinalmente no sentido vestíbulo-lingual. As seções foram observadas quanto à microinfiltração em estereomicroscópio. Foram estabelecidos quatro escores para a penetração do corante. Todos os materiais exibiram algum grau de microinfiltração e não houve diferença estatisticamente significante entre os grupos $(\mathrm{p}>0,05)$. Concluiu-se que a resina composta flowable, o compômero e o cimento de ionômero de vidro modificado por resina apresentaram capacidade de selamento marginal semelhante à do selante resinoso autopolimerizável sem carga.

\section{ACKNOWLEDGEMENTS}

This study was supported by a grant-in-aid from FAPESP (\# 02/ 00156-6). The authors express their gratitude to Mr. Marcos Blanco Cangiani, technician of the Laboratory of Dental Materials at the Faculty of Dentistry of Piracicaba (UNICAMP), Brazil.

\section{REFERENCES}

1. Newbrun E. Preventing dental decays: current and prospective strategies. J Am Dent Assoc 1992;123:68-73.

2. Kaste LM, Selwitz RH, Oldakowski RJ, Brunelle JA, Winn DM, Brown LJ. Coronal caries in primary and permanent dentition of children and adolescents 1-17 years of age: United States, 1988-1991. J Dent Res 1996;75:631-641.

3. Pereira AC, Castellanos RA, da Silva SR, Watanabe MG, Queluz DP, Meneghim MC. Oral health and periodontal status in Brazilian elderly. Braz Dent J 1996;7:97-102.

4. Simonsen RJ. Pit and fissure sealant: review of the literature. Pediatr Dent 2002;24:393-414.

5. Ricketts D, Kidd E, Weerheijm K, de Soet H. Hidden caries: what is it? Does it exist? Does it matter? Inter Dent J 1997; 47:259-265.

6. Millman CK. Fluoride syndrome. Br Dent J 1984;157:341.

7. Kidd EAM. Microleakage: a review. J Dent 1976;4:199-204.

8. Pérez-Lajarin L, Cortés-Lillo O, García-Ballesta C, Cózar- 
Hidalgo A. Marginal microleakage of teo fissure sealants: a comparative study. J Dent Child 2003;70:24-28.

9. Pereira AC, Basting RT, Pinelli C, de Castro Meneghim M, Werner CW. Retention and caries prevention of Vitremer and Ketac-Bond used as occlusal sealants after 6 and 12 months. Am J Dent 1999;12:62-64.

10. dos Santos PH, Consani S, Correr Sobrinho L, Coelho Sinhoreti MA. Effect of surface penetrating sealant on roughness of posterior composite resins. Am J Dent 2003 Jun;16:197-201.

11. Zervou C, Kugel G, Leone C, Zavras A, Doherty EH, White GE. Enameloplasty effects on microleakage of pit and fissure sealants under load: an in vitro study. J Clin Pediatr Dent 2000;24:279-285.

12. Rego MA, Araújo MA. Microleakage evaluation of pit and fissure sealants done with different procedures, materials, and laser after invasive technique. J Clin Pediatr Dent 1999;24:6368.

13. Güngör HC, Turgut MD, Attar N, Altay N. Microleakage evaluation of flowable polyacid-modified resin composite used as fissure sealant on air-abraded permanent teeth. Oper Dent 2003;28:267-273.

14. American Dental Association. Dental sealants. ADA Council on access, prevention and interprofessional relations; ADA council on scientific affairs. J Am Dent Assoc 1997;128:485488.

15. Weerheijm KL, de Soet JJ, de Graaff J, van Amerongen WE. Occlusal hidden caries: a bacteriological profile. J Dent Child 1990;57:428-432.

16. Jensen OE, Handelman SL. Effect of an autopolymerizing sealant on viability of microflora in occlusal dental caries. Scand J Dent Res 1980;88:382-388.

17. Weerheijm KL, Groen HJ. The residual caries dilemma. Community Dent Oral Epidemiol 1999;27:436-441.

18. Mertz-Fairhurst EJ, Smith CD, Williams JE, Sherrer JD, Mackert JR Jr, Richards EE, Schuster GS, O’Dell NL, Pierce KL, Kovarik RE, Ergle JW. Cariostatic and ultraconservative sealed restorations: six-year results. Quintessence Int 1992;23:827-838.

19. Kramer PF, Zelant F, Simionato MR. The immediate and long-term effects of invasive and non-invasive pit and fissure sealing techniques on the microflora in occlusal fissures of human teeth. Pediatr Dent 1993;15:108-112.

20. Handelman SL, Leverett DH, Iker HP. Longitudinal radiographic evaluation of the progress of caries under sealants. J Pedod 1985;9:119-126.

Accepted May 7, 2005 